\title{
Gender and environment: general and monthly gender distribution of newborns and cosmophysical parameters
}

\author{
Eliyahu Stoupel ${ }^{1,2 *}$, Evgeny Abramson ${ }^{3}$, Peter Israelevich ${ }^{4}$, Mordechai Shohat $^{2,5}$, \\ Jaqueline Sulkes ${ }^{3}$ \\ ${ }^{1}$ Division of Cardiology, Rabin Medical Center, Petah Tiqwa, Israel; *Corresponding Author: stoupel@inter.net.il \\ ${ }^{2}$ Sackler Faculty of Medicine Tel Aviv University, Tel Aviv; Israel \\ ${ }^{3}$ Management Data Center, Rabin Medical Center, Petah Tiqwa, Israel \\ ${ }^{4}$ Department of Geophysics \& Planetary Science, Tel Aviv University, Tel Aviv; Israel \\ ${ }^{5}$ Recanati Institute of Medical Genetics, Rabin Medical Center, Petah Tiqwa, Israel
}

Received 23 March 2010; revised 27 April 2010; accepted 28 April 2010.

\section{ABSTRACT}

Recent publications have described a relationship between fluctuations in environmental physical activity and several aspects of fetal development. This study explored the possible effects of cosmophysical parameters on newborn gender, overall and by maternal age. The gender distribution of 123,368 infants born over a 189-month period (November 1993-July 2009) was analyzed against levels of solar, geomagnetic, and cosmic ray activity at the time of conception. The cohort was then divided into three groups by maternal age ( $<28$ years, $29-35$ years, > 35 years) for further analysis. Pearson correlation coefficients and their probabilities were calculated, and chi-square test was applied, as necessary. The physical data were derived from space science centers in the USA, Russia, and Finland. The results showed that the male/female ratio for the whole cohort over the study period was 1.06 . However, on monthly analysis, there was a significant male predominance in most months, with a male/female ratio of up to 4. Younger mothers ( $\leq 28$ years) gave birth to significantly more boys than older mothers. The gender distribution in the three maternal age groups was partially linked to the different physical factors. These findings suggest that environmental physical activity in the month of conception may play a role in newborn gender. Further study is needed to determine the mechanism underlying this effect.

Keywords: Newborn; Gender; Solar; Geomagnetic;
Cosmic Ray; Activity; Age; Mother; Pregnancy

\section{INTRODUCTION}

Newborn gender is a focus of human and scientific interest. In addition to the known genetic factors that affect fetal development, several studies published in the last decades have considered the potential influence of fluctuations in environmental physical activity (solar, geomagnetic, cosmic ray) on physiologic and pathologic aspects of pregnancy and fetal development [1-9].

The aim of the present study was to investigate the possible effect of fluctuations in cosmophysical parameters at conception on newborn gender distribution, overall and by maternal age.

\section{METHODS}

The study included all 123,368 infants born at a tertiary university hospital in Israel from November 1993 to July 2009 (189 months): 63,415 male and 59,953 female (liveborn or stillborn). Distribution by maternal age showed that $54,158(43.86 \%)$ infants were born to mothers younger than 29 years, $47,655(38.60 \%)$ to mothers aged 29-35 years, and 21,657 (17.54\%) to mothers older than 35 years. These data were correlated against levels of the following cosmophysical parameters in the month of conception: solar activity indices- sunspot number, smoothed sunspot number, solar flux at $2800 \mathrm{MGH}$ and $10.7 \mathrm{~cm}$ wavelength, and adjusted solar flux; geomagnetic activity (GMA) indices-Ap, Cp, and Am (planetary and regional, for middle latitudes); and cosmic ray activity (CRA) - represented by neutron activity at the Earth's surface (in imp/min). The cosmophysical data for 
the study period were derived from weekly and monthly calculations published by space science institutions in the United States, Russia, and Finland that regularly monitor these parameters worldwide (National Geophysical Data Center, Space Weather Prediction Center, Moscow Neutron Monitor, Space Weather Prediction Center; Space Environment Services Center; November 2003-July 2009) [10-15].

\subsection{Statistical Analysis}

Pearson correlation coefficients (r) and their probabilities (p) were calculated between newborn gender distribution and the physical parameters. Chi-square test was used to analyze the likelihood of a newborn being male or female by physical parameters and maternal age group. Probabilities of $95 \%$ and higher were considered significant, probabilities of $90 \%-94 \%$ were considered trends toward significance. Non significant results were marked N.S.

\section{RESULTS}

The male/female ratio in the whole population of newborns was 1.06. Maximal monthly deviations ranged from 1.387 to 0.7399 . One hundred fifty months $(79.36 \%)$ were characterized by a significant prevalence of male newborns $(79.36 \%)$, and 39 months $(20.1 \%)$ by a sig- nificant prevalence of female newborns; in one month, the gender distribution was equal.

Table 1 presents the newborn gender relationship with cosmophysical parameters during the month of conception. Table 2 presents the same relationship by maternal age group: 28 years or less; 29-35 years; and 35 years or more.

The results showed that mothers aged 28 years or less gave birth to significantly more male newborns than older mothers $\left(\chi^{2}=3.9, \mathrm{p}=0.047\right)$. The ratio of months with more male newborns to months with more female infants in this maternal age group was 2.62. In the two older groups, this ratio was $2.16(\mathrm{p}<0.0001)$.

The differences among the maternal age groups prompted our use of multifactorial analysis for each gender and each of the three maternal age groups to predict the chances of a mother of particular age giving birth to a boy or girl according to levels of the cosmophysical parameters. The findings are shown in Tables 3-5. Factors that failed to show a significant relationship in the total correlation study (Table 1) were included as significant in the subgroup of multifactorial analysis (for example, monthly GMA Cp for mothers older 35 years) (Tables 3-5).

The relationship of solar and neutron activity was also different among the three age groups, changing from a positive in the young mother group to an inverse relationship

Table 1. Monthly $(\mathrm{n}=189)$ newborn $(\mathrm{n}=123683)$ gender distribution by physcial parameters in the month of conception $($ Pearson correlation coefficients and their probabilities).

\begin{tabular}{|c|c|c|c|}
\hline \multirow[t]{2}{*}{ Parameters } & \multicolumn{3}{|c|}{ Physical Activity 9 Months to Delivery } \\
\hline & Male $(n=63415)$ & Female $(n=59953)$ & Ratio (1.06) \\
\hline Year & $0.72 \mathrm{p}<0.0001$ & $0.704 \mathrm{p}<0.0001$ & NS \\
\hline Month & NS & NS & NS \\
\hline \multicolumn{4}{|l|}{ Solar activity } \\
\hline Sunspot number & $0.21 \mathrm{p}=0.0039$ & $0.16 \mathrm{p}=0.02$ & NS \\
\hline Smoothed sunspot number & $0.24 \mathrm{p}=0.0012$ & $0.2 \mathrm{p}=0.0056$ & NS \\
\hline Solar flux $2800 \mathrm{MGH}, 10.7 \mathrm{~cm}$ & $0.3 \mathrm{p}<0.0001$ & $0.26 \mathrm{p}=0.0003$ & NS \\
\hline Adjusted solar flux & $0.283 \mathrm{p}<0.0001$ & $0.243 p=0.0008$ & NS \\
\hline \multicolumn{4}{|l|}{ Geomagnetic activity } \\
\hline Ap & NS & NS & NS \\
\hline $\mathrm{Cp}$ & NS & NS & NS \\
\hline $\mathrm{Am}$ & NS & NS & NS \\
\hline \multicolumn{4}{|c|}{ Cosmic ray (neutron) activity (imp/min) } \\
\hline Moscow & $-0.295 \mathrm{p}<0.0001$ & $-0.28 p=0.0001$ & NS \\
\hline Oulo & $-0.27 p=0.0002$ & $-0.25 p=0.0005$ & NS \\
\hline
\end{tabular}

Note: 150 months, more males; 39 months, more females Chi-square $=134.8, \mathrm{p}<0.0001$; range: 1.387-0.7399. 
Table 2. Monthly $(n=189)$ gender distribution by environmental physical activity in month of conception and maternal age (Pearson correlation coefficients and their probabilities).

\begin{tabular}{|c|c|c|c|c|c|c|}
\hline \multirow[t]{2}{*}{ Parameter } & \multicolumn{2}{|c|}{ Age $\leq 28$} & \multicolumn{2}{|c|}{ Age 29-35 } & \multicolumn{2}{|c|}{ Age $>35$} \\
\hline & $\begin{array}{c}\text { Male } \\
(\mathrm{n}=27997)\end{array}$ & $\begin{array}{c}\text { Female } \\
(\mathrm{n}=26161)\end{array}$ & $\begin{array}{c}\text { Male } \\
(\mathrm{n}=\mathbf{2 4 3 5 2})\end{array}$ & $\begin{array}{c}\text { Female } \\
(\mathrm{n}=\mathbf{2 3 3 0 3})\end{array}$ & $\begin{array}{c}\text { Male } \\
(\mathrm{n}=11168)\end{array}$ & $\begin{array}{c}\text { Female } \\
(\mathrm{n}=10489)\end{array}$ \\
\hline Year & $\begin{array}{c}0.263 \\
0.0003\end{array}$ & $\begin{array}{c}0.233 \\
0.0013\end{array}$ & $\begin{aligned} & 0.88 \\
< & 0.0001\end{aligned}$ & $\begin{aligned} & 0.86 \\
< & 0.0001\end{aligned}$ & $\begin{aligned} & 0.68 \\
< & 0.0001\end{aligned}$ & $\begin{array}{l}0.735 \\
0.0001\end{array}$ \\
\hline Month & NS & NS & NS & NS & NS & NS \\
\hline \multicolumn{7}{|l|}{ Solar activity } \\
\hline Sunspot number & $\begin{aligned} & 0.46 \\
< & 0.0001\end{aligned}$ & $\begin{aligned} & 0.44 \\
< & 0.0001\end{aligned}$ & NS & NS & $\begin{array}{l}-0.19 \\
0.0085\end{array}$ & $\begin{array}{l}-0.21 \\
0.0031\end{array}$ \\
\hline Smoothed sunpsot number & $\begin{aligned} & 0.51 \\
< & 0.0001\end{aligned}$ & $\begin{aligned} & 0.49 \\
< & 0.0001\end{aligned}$ & NS & NS & $\begin{array}{l}-0.2 \\
0.0057\end{array}$ & $\begin{array}{l}-0.2 \\
0.0055\end{array}$ \\
\hline $\begin{array}{l}\text { Solar flux } 2800 \text { MGH, } 10.7 \\
\mathrm{~cm}\end{array}$ & $\begin{aligned} & 0.53 \\
< & 0.0001\end{aligned}$ & $\begin{aligned} & 0.51 \\
< & 0.0001\end{aligned}$ & $\begin{array}{l}0.13 \\
0.08\end{array}$ & NS & $\begin{array}{c}-0.12 \\
0.1\end{array}$ & $\begin{array}{c}-0.13 \\
0.07\end{array}$ \\
\hline Adjusted solar flux & $\begin{array}{c}0.51 \\
0.0001\end{array}$ & $\begin{aligned} & 0.49 \\
< & 0.0001\end{aligned}$ & $\begin{array}{l}0.12 \\
0.09\end{array}$ & NS & $\begin{array}{c}-0.13 \\
0.07\end{array}$ & $\begin{array}{l}-0.14 \\
0.049\end{array}$ \\
\hline \multicolumn{7}{|l|}{ Geomagnetic activity } \\
\hline Ap & NS & NS & NS & NS & $\begin{array}{c}-0.12 \\
0.1\end{array}$ & $\begin{array}{l}-0.17 \\
0.018\end{array}$ \\
\hline $\mathrm{Cp}$ & NS & NS & $\begin{array}{c}-0.17 \\
0.02\end{array}$ & $\begin{array}{l}-0.16 \\
0.03\end{array}$ & $\begin{array}{l}-0.17 \\
0.018\end{array}$ & $\begin{array}{c}-0.2 \\
0.0055\end{array}$ \\
\hline $\mathrm{Am}$ & $\begin{array}{l}0.13 \\
0.07\end{array}$ & NS & NS & NS & $\begin{array}{l}-0.14 \\
0.056\end{array}$ & $\begin{array}{l}-0.165 \\
0.023\end{array}$ \\
\hline \multicolumn{7}{|c|}{ Cosmic ray (neutron) activity (imp/min) } \\
\hline Moscow & $\begin{array}{l}-0.465 \\
<0.0001\end{array}$ & $\begin{array}{l}-0.44 \\
<0.0001\end{array}$ & $\begin{array}{l}-0.16 \\
0.025\end{array}$ & $\begin{array}{c}-0.14 \\
0.06\end{array}$ & $\begin{array}{c}0.15 \\
0.033\end{array}$ & $\begin{array}{l}0.134 \\
0.065\end{array}$ \\
\hline Oulo & $\begin{array}{c}-0.4 \\
<0.0001\end{array}$ & $\begin{array}{c}-0.34 \\
<0.0001\end{array}$ & $\begin{array}{c}-0.17 \\
0.02\end{array}$ & $\begin{array}{c}-0.16 \\
0.03\end{array}$ & $\begin{array}{c}0.14 \\
0.057\end{array}$ & $\begin{array}{c}0.12 \\
0.1\end{array}$ \\
\hline
\end{tabular}

Table 3. Prediction model to determine likelihood of a woman older than 29 years giving birth to a male or female infant by levels of physical factors in the month of conception.

\begin{tabular}{lccc}
\hline \multicolumn{1}{c}{ Variables } & Parameter estimate & Standard error & Probability \\
\hline Likelihood of male infant $(\mathbf{n}=\mathbf{2 7 8 9 7})$ & & & $<0.0001$ \\
Intercept & -3569 & 621.2 & $<0.0001$ \\
Year & 1.85 & 0.311 & $<0.01$ \\
Solar flux 2800 MGH & 2.485 & 0.436 & $<0.0001$ \\
Adjusted solar flux & -2.54 & 0.454 & 0.0012 \\
Smoothed sunspot number & 0.4 & 0.123 & $<0.0001$ \\
Likelihood of female infant $(\mathbf{n}=\mathbf{2 6 1 6 1 )}$ & & & $<0.0001$ \\
Intercept & -3097 & 610.4 & $<0.0001$ \\
Year & 1.61 & 0.306 & $<0.0001$ \\
Solar flux 2800 MGH & 2.43 & 0.428 & 0.0016 \\
Adjusted solar flux & -2.5 & 0.446 & 0.12 \\
Smoothed sunspot number & 0.138 & & \\
\hline
\end{tabular}


Table 4. Prediction model to determine likelihood of a woman aged 29-35 years giving birth to a male or female infant by levels of physical factors in the month of conception.

\begin{tabular}{lccc}
\hline \multicolumn{1}{c}{ Variables } & Parameter estimate & Standard error & Probability \\
\hline Likelihood of male infant (n= 24352) & & & $<0.0001$ \\
Intercept & -12310 & 437 & $<0.0001$ \\
Year & 6.21 & 0.218 & 0.0071 \\
Month & 0.788 & 0.289 & $<0.0001$ \\
Smoothed sunspot number & 0.124 & 0.00257 & $<0.0001$ \\
Likelihood of female infant (n=23303) & & & $<0.0001$ \\
Intercept & -11071 & 469.76 & 0.08 \\
Year & 5.62 & 0.234 & 0.0028 \\
Month & 0.54 & 0.311 & 0.003 \\
CRA & -0.01 & & \\
\hline
\end{tabular}

CRA— cosmic ray activity

Table 5. Prediction model to determine likelihood of a woman older than 35 years giving birth to a male or female infant by levels of physical factors in the month of conception.

\begin{tabular}{|c|c|c|c|}
\hline Variables & Parameter estimate & Standard error & Probability \\
\hline \multicolumn{4}{|c|}{ Likelihood of male infant $(n=11166)$} \\
\hline Intercept & -4343 & 323 & $<0.0001$ \\
\hline Year & 2.16 & 0.159 & $<0.0001$ \\
\hline GMA (Cp) & 10.98 & 4.267 & $<0.01$ \\
\hline CRA & 0.011 & 0.00258 & $<0.0001$ \\
\hline \multicolumn{4}{|c|}{ Likelihood of female infant $(n=10489)$} \\
\hline Intercept & -4339 & 288.08 & $<0.0001$ \\
\hline Year & 2.167 & 0.14 & $<0.0001$ \\
\hline GMA (Cp) & 19.98 & 4.267 & $<0.001$ \\
\hline CRA & 0.0062 & 0.00158 & 0.0001 \\
\hline
\end{tabular}

GMA—geomagnetic activity, CRA—cosmic ray activity

in the older than 35. In the intermediate age group (age 28-35) non significant relationship was seen (Table 2).

\section{DISCUSSION}

Newborn gender is known to be affected by genetic (chromosome X, Y interaction) and endocrine (hormonal) factors [16,17]. A series of publications has demonstrated that environmental physical parameters, such as solar, cosmic ray and geomagnetic activity, at the beginning of pregnancy may also play a role [1-9,17-19], perhaps via their effects on chromosome function (clearly shown in the case of Down syndrome) and hormone secretion [5] Accordingly, other neonatology parameters, including monthly number of infants born, newborn length and weight, preterm deliveries, and occurrence of congenital heart disease and other malformations have been linked to cosmophysical activity $[1-6,9,15,17,19$, 20]

The mechanism underlying this relationship is still unknown, although the physiologic and teratogenic potential of cosmophysical factors is clear. The effect of solar activity on human biological behavior is apparently due to solar corpuscular and wave energy. High levels of 
cosmic rays in space leave remains of crushed atoms in the form of neutrons, and the measurement of neutron activity on the Earths' surface serves as an indirect measure of cosmic ray activity. It is assumed that neutrons, by the nature of their physical properties, connect with $\mathrm{H}^{+}$ions and are converted to protons, which attack cell nuclei in enzymes and other regulatory systems $[19,21]$. Solar and geomagnetic activities shield the Earth from cosmic rays; when they are weak, the effect of cosmic ray activity increases. One study conducted over a 216-month period found that the correlation between solar and cosmic ray activity was -0.84 ( $\mathrm{p}<$ 0.0001 ) [22,23]. Recent study, describing the Y chromosome as a very labile structure [24], allows to see it as an object for possible physical influences.

According to the world-renowed physicist, Dr. Feinmann, "Probably the most powerful single assumption that contributes to the progress of biology is the assumption that everything from the animals to the atoms can do that are seen in the biological world are the result of the behavior of physical and chemical phenomena" [25].

Overall, we found that the number of male newborns only slightly surpassed the number of female newborns. A male/female ratio of 1.06 to 1.07 has been consistently reported in studies in various countries and regions [6]. However, males showed a considerable predominance when we compared monthly deliveries: in some months, the male/female ratio was close to 4 . This trend was more apparent in younger mothers (age 28 years or less). Further analysis of gender distribution by maternal age showed that in the youngest age group, solar activity had a strong effect and cosmic ray activity a weak effect, whereas in the older groups, this relationship was reversed. Given that the youngest group was larger, our findings for the overall link of monthly gender distribution with physical factors were close to those for the youngest group.

Although we focused only on maternal age in this study, we assume a concomitant younger age of the fathers as well, which may also play a role in the physical influences at the time of conception.

The presented data constitute another chapter in the study of clinical cosmobiology and the opposing physical forces in our environment ("equilibrium paradigm") [26]. The link between the physical environmental and human homeostasis brings to mind the statement of Albert Einstein: "The human will is free only within the bounds of a determined cosmic system" [27].

\section{CONCLUSIONS}

Both gender monthly newborn number is linked with the level of cosmophysical activity.
Overall, there is a small male prevalence among newborns, although monthly calculation of this relationship reveals a considerable male predominance. In addition to other known factors that determine newborn gender, environmental physical activity during the month of conception may also be involved.

The relationship of the different physical factors with newborn gender varies by maternal age.

More studies are needed to further our understanding of the ways in which physical forces affect newborn gender.

\section{REFERENCES}

[1] Merlob, P., Raisner, S.H., Shimshoni, M. and Stoupel, E. (1989) Fetal growth in periods of extreme solar activity. Journal Foetal Medicine, 9(1-2), 1-4.

[2] Stoupel, E., Keret, R., Assa, S., Kaufman, H., Shimshoni, M. and Laron, Z. (1983) Secretion of growth hormone, prolactin and corticosteroids during different levels of of geomagnetic activity. Neuroendocrinology Letters, 5(6), $1-4$.

[3] Stoupel, E., Silbergeld, A., Gil-Ad, I., Keret, R., Shimshoni, M. and Laron, Z. (1989) Relationship between solar activity and levels of of plasma growth hormone and prolactin. Neuroendocrinology Letters, 11(5), 1-9.

[4] Stoupel, E., Hod, M., Shimshoni, M., Fridman, S., Ovadia, J. and Keith, L. (1990) Monthly cosmic activity and pregnancy induced hypertension. Clinical \& Experimental Obstetrics \& Gynecology, 17(1), 7-12.

[5] Stoupel, E., Frimer, H., Appelman, Z., Ben-Neriah, Z. Dar, H., Fejgin, M., Gershuni-Baruch, R., Manor, E., Barkai, G., Shalev, S., et al. (2005) Chromosome aberration and environmental physical activity: Down syndrome and solar activity, Israel, 1990-2000. International Journal of Biometeorology, 28(2), 1-9.

[6] Stoupel, E., Kalediene, R., Petrauskiene, J., Gaizauskiene, A., Israelevich, P., Abramson, E. and Sulkes. J. (2006) Monthly number of newborns and environmental physical activity. Medicina, 42(3), 238-242.

[7] Stoupel, E., Monselize, Y. and Lahav, J. (2006) Changes in autoimmune markers of the anti-cardiolipin syndrome on days of extreme geomagnetic activity. Journal of $\mathrm{Ba}$ sic and Clinical Physiology and Pharmacology, 17(4), 269-278.

[8] Stoupel, E., Sirota, L., Osovsky, M., Klinger, G., Abramson, E., Israelevich, P., Sulkes, J. and Linder, N. (2007) Monthly number of preterm births and environmental physical activity. Journal of Basic and Clinical Physiology and Pharmacology, 18(2), 149-157.

[9] Stoupel, E., Birk, E., Kogan, A., Klinger, G., Abramson, E., Israelevich, P., Sulkes, J. and Linder, N. (2009) Congenital heart disease: Correlation with fluctuations in cosmophysical activity, 1995-2005. International Journal of Cardiology, 135(2), 207-210.

[10] National Geophysical Data Center (monthly) Solar Activity Bulletin. Boulder, CO: NOAA/NGSD.

[11] National Geophysical Data Center (monthly) Geomagnetic Indices Bulletin. Boulder, CO: NOAA/NGSD. 
[12] Moscow Neutron Monitor. Neutron Monitor Data (daily, weekly). Izmiran Institute, Russian Academy of Sciences, Moscow.

[13] Neutron Monitoring Data. Monthly, Daily. Oulu University Neutron Monitoring Station. Oulu, Finland.

[14] Space Environment Services Center (1989) Glossary of Solar Terrestrial Terms. Boulder.

[15] Space Weather Prediction Center (weekly). Weekly Highlights and Forecasts. Boulder, CO: NOAA/NSWPC.

[16] Santolaya-Forges, J., Meyer, W.J., Burton, B. and Scommegna, A. (1999) Altered newborn gender distribution in patients with low mid-trimester maternal serum human chorionic gonadotropin. Journal of Maternal-Fetal Medicine, 6(2), 111-114

[17] Coutandt, R., Boux de Casson, F., Douay, O., Rouleau, S., Beringue, F., Gillard, P., Limal, J.M. and Descamps, P. (2001) Relationships between placental GH concentration and maternal smoking, newborn gender and maternal leptin: possible implications for birth weight. Journal of Clinical Endocrinology \& Metabolism, 86(10), 48544859.

[18] Archer, V.E. (1979) Anencephalus: Drinking water, geomagnetic and cosmic radiation. American Journal of Epidemiology, 109(1), 88-97.

[19] Kirby, A.J. and Hollfelder, F. (2008) Enzymes under the nanoscope. Nature, 456(7218), 45-47.
[20] Fenig, E., Michaeli, M., Kalish, Y. and Lishner, M. (2001) Pregnancy and radiation. Cancer Treatment Reviews, 27 (1), 1-7.

[21] Nias, A.W.H. (1998) An Introduction to Radiotherapy. John Wiley \& Sons, New York.

[22] Stoupel, E., Kalediene, R., Petrauskiene, J., Starkuviene, S., Abramson, E., Israelevich, P. and Sulkes, J. (2010) Death-optimal physical conditions. Journal of Basic and Clinical Physiology and Pharmacology, 21(1), 143-156.

[23] World Health Organization (2009) Genomic Resource Center. Gender and Genetics. http://www.who.int/genomics/gender/en/index4.html

[24] Hughes, J.F., Skaletsky, H., Pyntikova, T., Graves, T.A., Van Daalen, S.K.M., Minx, D.P., Fulton, R.S., Mcrath, S.D., Locke, D.P., Friedman, C., Trask, B.J., Mardis, E.R., Warren, W.C., Repping, S., Rozen, S., Wilkson, R.K. and Page, D.C. (2010) Chimpanzee and human Y chromosomes are remarkably divergent in structure and gene content. Nature, 463(7280), 536-539.

[25] Feinmann, R. (2003) Thoughts of a Citizen-Scientist. Perseus Books, Cambridge.

[26] Stoupel, E. (2002) The equilibrium paradigm in clinical cosmobiology. Journal of Basic and Clinical Physiology and Pharmacology, 13(3), 255-263.

[27] Einstein, A. (1932) Mein Weltbild. Europa Verlag, Zurich. 